\title{
Laparoscopic sleeve gastrectomy versus endoscopic intra-gastric balloon placement: Early results of morbidly obese patients
}

Laparoskopik sleeve gastrektomi ve endoskopik intragastrik balon uygulaması: Morbid obez hastalarda erken dönem sonuçlarımız

\section{Haci Murat Cayci ${ }^{1}$, Umut Eren Erdogdu ${ }^{1}$}

\begin{abstract}
Aim: Endoscopic intra-gastric balloon (IGB) placement and laparoscopic sleeve gastrectomy (LSG) are widely used treatment modalities for weight loss in patients with morbid obesity. The aim of our study was to evaluate the results of these two methods in patients with morbid obesity.

Methods: The data of 119 patients who were treated during the same time period for morbid obesity (Body Mass Index (BMI) $\geq 40 \mathrm{~kg} / \mathrm{m} 2$ ) and completed a 12 -month follow-up period were evaluated retrospectively. The study comprised twenty patients who underwent IGB placement and 99 LSG patients. Patients from these two groups were compared according to their demographic data; rate of comorbidity; weight and BMI changes both preoperatively and postoperatively at the 12 months; excess weight loss (EWL); and excess BMI loss (EBL).

Results: Evaluation of postoperative $12^{\text {th }}$ month weights showed a mean weight of $119.2 \pm 28.5 \mathrm{~kg}$ in the IGB group and $78.9 \pm 12.9 \mathrm{~kg}$ in the LSG group ( $\mathrm{p}<0.001)$. The patients in the IGB group had lost 26.3 $\pm 12.8 \mathrm{~kg}$ by the end of the $12^{\text {th }}$ month, while patients in the LSG group had lost $45.35 \pm 12.2 \mathrm{~kg}$ $(\mathrm{p}<0.001)$. EWL recorded at the postoperative $12^{\text {th }}$ month was $33.42 \pm 9.2 \%$ in the IGB group and 67.68 $\pm 14.9 \%$ in the LSG group ( $<<0.001$ ); EBL\% at the postoperative $12^{\text {th }}$ month was $41 \pm 17.3 \%$ in the IGB group and $81.48 \pm 18.8 \%$ in the LSG group $(\mathrm{p}<0.001)$.

Conclusion: In patients with morbid obesity, endoscopic IGB placement may still be preferred as an effective and safe alternative in patients who decline or are unsuitable for surgery.

Keywords: Morbid obesity, laparoscopic sleeve gastrectomy, intra-gastric balloon
\end{abstract}

Öz

Amaç: Morbid obes hastalarda kilo verilmesi için endoskopik intragastrik balon uygulaması (IGB) ve bariatrik cerrahi yöntemlerinden biri olan laparoskopik sleeve gastrektomi (LSG) yaygın olarak kullanılmaktadır. Çalışmamızda morbid obes hastalarda LSG ve İGB uygulanması sonuçlarımızın değerlendirilmesi amaçlanmıştır.

Yöntemler: Morbid Obesite (Vücut Kitle İndeksi-VKI $\geq 40 \mathrm{~kg} / \mathrm{m}^{2}$ ) nedeniyle aynı dönemde tedavi edilen ve 12 aylık takip dönemini tamamlayan 119 hastanın verileri retrospektif olarak değerlendirildi. Çalışmada İGB uygulanan 20 hasta ve LSG yapılan 99 hasta yer aldı. Hastaların demografik verileri, yandaş hastalık, preoperatif ve postoperatif 12. ayda kilo ve VKİ verileri, verilen fazla kilo ve yüzdeleri, verilen fazla VKİ ve yüzdeleri kaydedilip gruplar karşılaştırıldı.

Bulgular: LSG ve İGB grupları arasında preoperatif kilo açısından istatiksel anlamlı farklılık olduğu görüldü (sırasıyla $124,3 \pm 17$ ve $145,5 \pm 24,7 ; \mathrm{p}<0,001$ ). Postoperatif 12 . ayda ölçülen kilo değerlendirildiğinde İGB grubunda ortalama $119,2 \pm 28,5 \mathrm{~kg}$ ve LSG grubunda 78,9 $\pm 12,9 \mathrm{~kg}$ saptand $(\mathrm{p}<0,001)$. İGB grubundaki hastaların 12.ay sonunda ortalama $26,3 \pm 12,8 \mathrm{~kg}$ kilo verdiği, LSG grubundaki hastalarında $45,35 \pm 12,2 \mathrm{~kg}$ kilo verdiği görüldü $(\mathrm{p}<0,001)$. Postoperatif 12 . ayda saptanan verilen fazla kilo yüzdesi İGB grubunda $33,42 \pm 9,2 \%$, LSG grubunda $67,68 \pm 14,9 \%$ saptandı $(\mathrm{p} \prec 0,001)$. Postoperatif 12.ayda saptanan verilen fazla VKİ yüzdesi açısından İGB grubunda $41 \pm 17,3 \%$, LSG grubunda $81,48 \pm 18,8 \%$ saptandı $(\mathrm{p}<0,001)$.

Sonuç: Morbid obes hastalarda endoskopik IGB uygulaması cerrahiye uygun olmayan veya cerrahi tedaviyi tercih etmeyen hastalarda etkin ve güvenli bir tedavi seçeneği olarak tercih edilebilir.

Anahtar kelimeler: Morbid obezite, laparoskopik sleeve gastrektomi, intragastik balon

\section{Introduction}

Morbid obesity is an important cause of morbidity and mortality worldwide in itself, as well as leading to comorbidities associated with obesity (such as coronary artery disease, diabetes mellitus type 2 , insulin resistance, non-alcoholic steatohepatitis and hypertension) [1,2]. In the non-surgical treatment of morbid obesity, a weight loss of between 3 and $9 \%$ can be achieved in a period of one year as a result of dietary changes, medical treatments and regular exercise although these percentages may differ in Europe and in Eastern communities [3]. Various bariatric surgical methods and endoscopic intra-gastric balloon (IGB) placement are now widely used in the treatment of morbid obesity [4-10].
Bursa Yuksek Ihtisas Teaching and Research Hospital, Department of General Surgery, University of Health Sciences, Bursa, Turkey.

T.C. Sağlık Bilimleri Üniversitesi Bursa Yüksek İhtisas Eğitim ve Araştırma Hastanesi, Genel Cerrahi Kliniği, Bursa, Türkiye.

Ethical approval: Due to retrospective design of the study, no ethical approval has been taken.

Etik Kurul: Çalışmanın retrospektif dizaynından dolayı etik kurul onayı alınmamıștır.

Conflict of Interest: No conflict of interest was declared by the authors.

Çıkar Çatışması: Yazarlar çıkar çatışması bildirmemişlerdir.

Financial Disclosure: The authors declared that this case has received no financial support.

Finansal Destek: Yazarlar bu olgu için finansal destek almadıklarını beyan etmişlerdir.

Geliş Tarihi / Received

26.06.2017

Kabul Tarihi / Accepted

21.07.2017

Yayın Tarihi / Published

15.08.2017

Sorumlu yazar / Corresponding author

Haci Murat Cayci Address: Bursa Yuksek Ihtisas Teaching and Research Hospital, Department of General Surgery, University of Medical Sciences, Mimar Sinan Mah. Emniyet Caddesi, Yildirim, 16310, Bursa, Turkey

Tel: +905325434838

E-mail: hmurat.cayci@gmail.com

Copyright 2017 ACEM

IGB placement is used in morbidly obese patients who do not choose surgery, with the aim of achieving efficient weight loss but also treating accompanying comorbid disease symptoms, while avoiding the risks of a primary bariatric surgical process [4, 5]. As IGB placement is relatively fast and easy, it is widely used in obese patients. The aim of IGB is to achieve weight loss by providing an early feeling of satiety due to abdominal distension, thereby reducing the desire for food consumption, delaying gastric emptying and consequently attaining weight-loss [6]. 
Bariatric surgical practices are indicated for cases of clinically severe obesity, where it is the most effective treatment option for achieving an efficient and sustainable weight control [7]. Although bariatric surgery brings with it an increased perioperative risk related to morbid obesity and its accompanying comorbid situations, surgery does provide treatment for obesity and comorbid diseases, and thus decreases long-term mortality $[7,8]$. Even though bariatric surgical practices are effective, it should be remembered that only $1 \%$ of morbidly obese patients can be admitted for bariatric surgery [7]. On the other hand, laparoscopic sleeve gastrectomy (LSG) is a relatively new, restrictive and hormonally efficient surgical practice that has been used more frequently in the last decade $[9,10]$.

In this retrospective study, we aimed to determine the efficiency and early results of IGB placement and LSG used to treat morbid obese patients.

\section{Materials and methods}

\section{Patients}

The data of 119 patients who were treated at Bursa Yuksek Ihtisas Teaching and Research Hospital, Department of General Surgery between January 2014 and June 2015 for morbid obesity (BMI $\geq 40 \mathrm{~kg} / \mathrm{m}^{2}$ ) and who completed 12 months of follow-up was retrospectively evaluated. 20 patients who underwent IGB and 99 patients who underwent LSG during the same period were included in the study. Morbidly obese patients were evaluated in the preoperative period by a team composed of endocrinology, psychiatry, general surgery and chest disease specialists. The patients were apprised before IGB placement and LSG, and their informed consent was obtained. Institutional review board approval was taken. Our study was performed in accordance with the World Medical Association Declaration of Helsinki. Written consent from the patients could not be taken due to the retrospective design of the study.

\section{Study Design}

Patients between the ages of 20-60 with BMI $\geq 40$ $\mathrm{kg} / \mathrm{m}^{2}$, who had been advised to make changes in diet, exercise and lifestyle, however, did not achieved an efficient weight loss despite the recommendations for at least for 6 months were included. Within those patients, the ones who declined bariatric surgery were selected for IGB placement. Eleven patients that undergone previous bariatric surgery, patients that receive anticoagulant or steroid treatment and had alcohol or drug addiction in the time of surgery were excluded.

Demographic data, comorbidity, weight and BMI data preoperatively and postoperatively at the $12^{\text {th }}$ month, excess weight loss (EWL) and percentages, excess BMI loss (EBL) and percentages of the patients in the IGB and LSG groups were recorded and compared.

\section{Surgical and Endoscopic Techniques}

IGB placement was performed in the endoscopy unit under the supervision of an anesthesiologist. An adjustable balloon (Spatz3 Adjustable Balloon, NY, USA) that can be remained in the stomach for 12 months was preferred for IGB. Sedation was provided with intravenous sedative agents (Propofol, Pfizer, New York, USA) in the lateral decubitus position. Following upper gastrointestinal system endoscopy, assessment of any obstructive pathology that would contradict the process was made. Subsequently, IGB was placed at the edge of the gastroscope and brought to the fundus of the stomach. A solution of methylene blue $(10 \mathrm{ml})$ and saline $(540 \mathrm{ml})$ was released into IGB under direct vision. Methylene blue was used, as it would provide a change in urine color (green color) in case of rupture of the balloon. After the procedure, patients were hospitalized to evaluate IGB toleration. Patients who had no significant vomiting or abdominal pain were started on a liquid diet on the day after the procedure and were discharged from the hospital on the second day if they tolerated this diet. For the first week, the patients were restricted to a liquid diet only. After the first week, a low calorie diet, prepared by a dietician, was applied. If a patient's weight loss stopped during the follow-up period, a further $50 \mathrm{ml}$ saline was added to IGB in the endoscopy unit under sedation. After 12 months, the IGB was extracted from the patients in the endoscopy unit, under intravenous sedation.

All LSG procedures were performed by the same surgeon; the operations were performed in the Lloyd Davies position and a $34 \mathrm{~F}$ bougie was standard. The gastrectomy removed approximately $80 \%$ of the stomach, with the remnant stomach capacity of $<100 \mathrm{ml}$, and none of the cases required conversion to open surgery. All patients were given a liquid diet before the operation. In addition, the night before the operation, all patients were administered low molecular weight heparin (Enoxaparine, Sanofi, Paris, France) subcutaneously for deep venous thrombosis prophylaxis and were dressed with pneumatic compression stockings. A liquid diet was started following flatus discharge from the anus in the postoperative period. The patients who tolerated oral intake and had no morbidity development were discharged from the hospital on the fourth postoperative day.

All patients who underwent IGB placement and LSG had weight follow-ups in the $1^{\text {st }}, 3^{\text {rd }}, 6^{\text {th }}$ and $12^{\text {th }}$ postoperative months.

\section{Statistical Analysis}

Statistical analysis was performed with IBM Statistical Package for Social Sciences (SPSS) for Windows, version 21.0 (SPSS. Inc., Chicago, IL). Distribution of continuous numerical variables was assessed with histograms and the Shapiro-Wilk test. Continuous numerical variables were reported as mean, standard deviation and minimum-maximum, and categorical variables as case number and percentage (\%). Related samples Wilcoxon Test and Paired and Independent Samples T test were used for the comparison of preoperative and postoperative parameter averages. The results were accepted as statistically meaningful when the $\mathrm{p}$ value was $<0.05$.

\section{Results}

Demographic features of the patients who underwent IGB placement or LSG and the data on comorbidity, morbidity and mortality were given in Table 1 . In the study, there were 20 $(16.8 \%)$ patients in the IGB group and $99(83.2 \%)$ in the LSG group. The rate of accompanying comorbidity was $11(55 \%)$ in the IGB group and $30(30.3 \%)$ in the LSG group. The comorbidities in the IGB group were coronary artery disease in one $(5 \%)$ patient; hypertension in three $(15 \%)$ patients; type 2 diabetes mellitus in four (20\%) patients; and both type 2 diabetes mellitus and hypertension in three $(15 \%)$ patients. In the LSG group, coronary artery disease was detected in two $(2.02 \%)$ patients, hypertension in nine $(9.09 \%)$ patients, type 2 diabetes mellitus in $11(11.1 \%)$ patients, and both type 2 diabetes mellitus and hypertension in eight $(8.08 \%)$ patients. Therefore, the presence of comorbidity was higher and statistically significant in the IGB group $(\mathrm{p}=0.034)$. 
Table 1: Demographic data, comorbidity, morbidity and mortality data of the patients who underwent IGB placement and LSG.

\begin{tabular}{lccc} 
& $\begin{array}{c}\text { IGB } \\
(\mathrm{n}=20)\end{array}$ & $\begin{array}{c}\text { LSG } \\
(\mathrm{n}=99)\end{array}$ & $\mathrm{p}$ value \\
\hline Age (year) & $39.8 \pm 9.6$ & $36.6 \pm 9.9$ & 0.188 \\
Gender M/F & $3 / 17$ & $10 / 89$ & 0.457 \\
Comorbidity & $11(55 \%)$ & $30(30.3 \%)$ & 0.034 \\
$\mathrm{n}(\%)$ & & $3(3.03 \%)$ & - \\
Morbidity n $(\%)$ & - & - & - \\
Mortality n $(\%)$ & - & & \\
\hline
\end{tabular}

M: Male, F: Female, IGB: Intra-Gastric Balloon, LSG: Laparoscopic Sleeve Gastrectomy

While morbidity was not seen in the IGB group, it was seen in three $(3.03 \%)$ patients in the LSG group. Postoperative hemorrhage occurred in these three $(3.03 \%)$ patients, while the patients who were hemodynamically stable were followed-up conservatively. Nausea and vomiting and abdominal pain were seen in $11(55 \%)$ and $5(25 \%)$ patients in the IGB group, respectively. But no significant lesion such as gastric ulcer or mucosal erosion was detected. As three (15\%) IGB patients could not lose sufficient weight during their follow-up period; the volume of their balloons was increased by $50 \mathrm{ml}$ in the endoscopy unit. There was no mortality in any of the groups.

Weight and BMI values recorded preoperatively and at the postoperative $12^{\text {th }}$ month; excess weight loss-EWL and percentage; excess BMI loss-EBL change and percentage data for both the IGB and LSG groups were given in Table 2.

Table 2: The values of weight and BMI preoperatively and at the postoperative $12^{\text {th }}$ month, EWL and EBL change and their percentage changes.

\begin{tabular}{lccc} 
& IGB $(\mathrm{n}=20)$ & LSG $(\mathrm{n}=99)$ & p value \\
\hline Preoperative weight $(\mathrm{kg})$ & $145.5 \pm 24.7$ & $124.3 \pm 17$ & $<0.001$ \\
Preoperative BMI $\left(\mathrm{kg} / \mathrm{m}^{2}\right)$ & $53.7 \pm 11.3$ & $50.9 \pm 4.9$ & 0.078 \\
$12^{\text {th }}$ month weight $(\mathrm{kg})$ & $119.2 \pm 28.5$ & $78.9 \pm 12.9$ & $<0.001$ \\
$12^{\text {th }}$ month BMI $\left(\mathrm{kg} / \mathrm{m}^{2}\right)$ & $43.29 \pm 11.1$ & $29.35 \pm 4.7$ & $<0.001$ \\
Weight loss $(\mathrm{kg})$ & $26.3 \pm 12.8$ & $45.35 \pm 12.2$ & $<0.001$ \\
Weight loss $(\%)$ & $18.07 \pm 10.5$ & $36.32 \pm 11.3$ & $<0.001$ \\
EWL $(\%)$ & $33.42 \pm 9.2$ & $67.68 \pm 14.9$ & $<0.001$ \\
EBL $(\%)$ & $41 \pm 17.3$ & $81.48 \pm 18.8$ & $<0.001$
\end{tabular}

BMI: Body Mass Index, EWL: Excess Weight Loss, EBL: Excess Body Mass Index Loss, IGB: Intra-Gastric Balloon, LSG: Laparoscopic Sleeve Gastrectomy

\section{Discussion}

Nowadays, following a world-wide trend, the prevalence of morbid obesity in Turkey is on the increase. The search for an efficient, safe treatment method with low complication rates and easy to apply still continues. IGB placement has been developed for this purpose and is used in tandem with advanced technology to provide weight control in morbidly obese patients [11]. IGB placement can deliver weight loss and also reduce comorbidity [12].

IGB placement is performed in patients who cannot lose enough weight with conservative treatment, who are not candidates for surgery or who do not wish to have surgical intervention [13]. In this procedure, balloons of different size and stability are used and can be inflated with air or liquid [11]; in our clinic, adjustable balloons that can be remained in the stomach for up to 12 months are used and inflated with saline. Accordingly, in our study, IGB content was increased by $50 \mathrm{ml}$ in 3 cases as sufficient weight loss had not been achieved. Using an IGB rather than bariatric surgery in morbidly obese patients means that there is no risk of decreasing the volume of the left hepatic lobe, but also that the general risks of definitive surgical intervention and anesthesia can be avoided [14]. None of our IGB patients were further been operated for obesity disease, thus they all are selected between the patients that declined bariatric procedure.

IGB placement is considered less efficient than definitive bariatric surgical interventions in terms of weight loss; but more effective than diet, exercise and lifestyle changes [15]. Moreover, initial BMI and the patient's motivation and compliance with the diet program significantly affect weight loss after IGB placement. Although IGB placement is efficient in the short term, its long-term effectiveness has not yet been welldefined [16].

Bariatric surgical interventions provide efficient weight loss and permanent weight control in morbidly obese patients [17]. When bariatric surgery is compared with IGB placement, it is more efficient but it has a higher risk ratio [4]. LSG was performed in our study and is reported to be an increasingly common method; it provides effective weight loss and comorbidity resolution in the management of obesity and has restrictive and hormonal effects [9, 10]. Some of its advantages are the absence of diarrhea or dumping syndrome as the pylorus and duodenum are protected; avoidance of serious malabsorption; the absence of anastomosis; and simplicity of the technique.

In our study, we also observed that the patients who underwent LSG achieved better weight loss during the one-year follow-up period compared to patients who received IGB $(45.35$ \pm 12.1 and $26.3 \pm 12.84$, respectively) $(\mathrm{p}<0.001)$. When the EWL\% was evaluated after one postoperative year, the LSG group recorded better results than the IGB group $(67.68 \pm 14.9 \%$; $33.42 \pm 9.2 \%$ respectively) $(\mathrm{p}<0.001)$. The EBL\% of the LSG group in the first postoperative year was also significantly different from the IGB group $(81.48 \pm 18.8 \%$ and $41 \pm 17.3 \%$, respectively) $(\mathrm{p}<0.001)$. Overall our study shows that LSG is more efficient than IGB placement in treating morbidly obese patients, a result which is compatible with the literature $[15,17]$.

According to the literature, following IGB placement, the mean weight loss is $17.8-24.4 \mathrm{~kg}$, and the EWL ratio is $48 \%$ $[18,19]$. After IGB placement, $33.7 \%$ and $29 \%$ of the patients report abdominal pain and nausea, respectively [20]. Certain complications after IGB placement are also reported, such as small bowel obstruction $(0.3 \%)$, spontaneous balloon deflation $(6 \%)$, balloon migration $(1.4 \%)$, gastric mucosal injury $(2 \%)$ and mortality at a rate of $0.08 \%$ [20]. In our study, there was no morbidity or mortality among our IGB cases. All patients have not seen problem to keep balloon for 1 year in IGB application.

LSG provides efficient weight loss in morbidly obese patients. Although a considerable decline in mortality is achieved after LSG, reported rates of early and late period morbidity vary between $9 \%$ and $23 \%$, leakage is recorded at $1 \%-6 \%$ and hemorrhage as $2 \%$ and $7.3 \%$ [21, 22]. Leakage development after LSG is an important cause of morbidity and mortality [23]. Patients with BMI> 50, use of a dilator with a diameter less than $40 \mathrm{~F}$, and revision surgery were defined as independent risk factors for development of leakage [24, 25].

In our study, hemorrhage developed in the postoperative period at a rate of $3.03 \%$ and was treated conservatively. Studies report a EWL\% that ranges from $49 \%$ to $81 \%$ after LSG; and a postoperative BMI that varies between 24.4 and $32 \mathrm{~kg} / \mathrm{m}^{2}$ [2628]. In our study, in the first year after LSG, the EWL\% was recorded as $67.68 \pm 14.9 \%$ and the EBL as $81.48 \pm 18.8 \%$. Therefore, our results following LSG were consistent with the literature.

There are some limitations to our study; namely, the relatively low number of cases and the single-centered, retrospective nature of the study. 
In conclusion, in morbid obesity treatment, LSG and IGB provide efficacy to different degrees. The most efficient treatment option for morbidly obese patients to achieve and maintain weight loss is a bariatric intervention, such as LSG. However, IGB placement may be preferred as an efficient and safe treatment method for morbidly obese patients who do not prefer surgical treatment or whose general health conditions do not allow surgical intervention. In order to clarify the role of IGB placement in morbid obesity treatment, we believe that further studies, with larger cohorts of patients and including short and long term results, are needed.

\section{References}

1. Prospective Studies Collaboration, Whitlock G, Lewington S, Sherliker P, Clarke R, Emberson J, Halsey J, et al. Body-mass index and causespecific mortality in 900000 adults: collaborative analyses of 57 prospective studies. Lancet 2009;373:1083-96.

2. Guh DP, Zhang W, Bansback N, Amarsi Z, Birmingham CL, Anis AH. The incidence of comorbidities related to obesity and overweight: a systematic review and meta-analysis. BMC Public Health 2009;9:88.

3. Yanovski SZ, Yanovski JA. Long-term drug treatment for obesity: a systematic and clinical review. JAMA 2014;311:74-86.

4. ASGE/ASMBS Task Force on Endoscopic Bariatric Therapy, Ginsberg GG, Chand B, Cote GA, Dallal RM, Edmundowicz SA, Nguyen NT, et al. A pathway to endoscopic bariatric therapies. Gastrointest Endosc 2011;74:943-53.

5. Poobalan AS, Aucott LS, Smith WC, Avenell A, Jung R, Broom J. Long-term weight loss effects on all cause mortality in overweight/ obese populations. Obes Rev 2007;8:503-13.

6. Mathus-Vliegen EM. Endoscopic treatment: the past, the present and the future. Best Pract Res Clin Gastroenterol 2014;28:685-702.

7. Buchwald H, Oien DM. Metabolic/bariatric surgery worldwide 2011. Obes Surg 2013;23:427-36.

8. Adams TD, Davidson LE, Litwin SE, Kolotkin RL, LaMonte MJ, Pendleton RC, et al.Health benefits of gastric bypass surgery after 6 years. Jama 2012;308:1122-31.

9. Sarela AI, Dexter SP, O'Kane M, Menon A, McMahon MJ. Long-term follow-up after laparoscopic sleeve gastrectomy: 8-9-year results. Surg Obes Relat Dis 2012;8:679-84.

10. Cayci HM, Erdogdu UE, Karaman K, Budak E, Taymur İ, Buyukuysal C. Does Weight Gain During the Operation Wait Time Have an Impact on weight Loss After Laparoscopic Sleeve Gastrectomy?. Obes Surg 2017;27:338-42.

11. Gleysteen JJ. A history of intragastric balloons. Surg Obes Relat Dis 2016;12:430-5

12. Genco A, Bruni T, Doldi SB, Forestieri P, Marino M, Busetto L, et al BioEnterics Intragastric Balloon: the Italian experience with 2.515 patients. Obes Surg 2005;15:1161-4.

13. Göttig S, Daskalakis M, Weiner S, Weiner RA. Analysis of safety and efficacy of intragastric balloon in extremely obese patients. Obes Surg 2009; 19:677-83

14. Coskun H, Bostanci O, Dilege E, Bozbora A. BioEnterics intragastric balloon: clinical outcomes of the first 100 patients - a Turkish experience. Obes Surg 2008;18:1154-6.

15. Mui WL, Ng EK, Tsung BY, Lam CH, Yung MY. Impact on obesityrelated illnesses and quality of life following intragastric balloon. Obes Surg 2010;20:1128-32.

16. Imaz I, Martínez-Cervell C, García-Alvarez EE, Sendra-Gutiérrez JM, González-Enríquez J. Safety and effectiveness of the intragastric balloon for obesity. A meta-analysis. Obes Surg 2008;18:841-6.

17. Casazza K, Fontaine KR, Astrup A, Birch LL, Brown AW, Bohan Brown MM, et al. Myths, presumptions, and facts about obesity. N Engl J Med 2013;368:446-54.

18. Dumonceau JM. Evidence-based review of the Bioenterics intragastric balloon for weight loss. Obes Surg 2008; 18:1611-7.

19. Machytka E, Klvana P, Kornbluth A, Peikin S, Mathus-Vliegen LE, Gostout C, et al. Adjustable intragastric balloons: a 12-month pilot trial in endoscopic weight loss management. Obes Surg 2011;21:1499-507.

20. ASGE Bariatric Endoscopy Task Force; ASGE Technology Committee, Abu Dayyeh BK, Edmundowicz SA, Jonnalagadda S, Kumar N, Larsen M, Sullivan S, et al. Endoscopic bariatric therapies. Gastrointest Endosc 2015;81:1073-86.

21. Chang SH, Stoll CR, Song J, Varela JE, Eagon CJ, Colditz GA. The effectiveness and risks of bariatric surgery: an updated systematic review and meta-analysis, 2003-2012. JAMA Surg 2014;149:275-87.
22. Benaiges D, Más-Lorenzo A, Goday A, Ramon JM, Chillarón JJ, PedroBotet J, et al. Laparoscopic sleeve gastrectomy: More than a restrictive bariatric surgery procedure? World J Gastroenterol 2015;21:11804-14.

23. Özgüç H, Narmanlı M, Duman E. Treatment of sleeve gastrectomy leak with an endoscopic stent. Ulus Cerrahi Derg 2014;30:169-72.

24. Sakran N, Goitein D, Raziel A, Keidar A, Beglaibter N, Grinbaum R, et al. Gastric leaks after sleeve gastrectomy: a multicenter experience with 2,834 patients. Surg Endosc 2013;27:240-45.

25. Rosenthal RJ; International Sleeve Gastrectomy Expert Panel, Diaz AA, Arvidsson D, Baker RS, Basso $\mathrm{N}$, et al. International Sleeve Gastrectomy Expert Panel Consensus Statement: best practice guidelines based on experience of $>12,000$ cases. Surg Obes Relat Dis 2012;8:8-19.

26. Schauer PR, Kashyap SR, Wolski K, Brethauer SA, Kirwan JP, Pothier $\mathrm{CE}$, et al. Bariatric surgery versus intensive medical therapy in obese patients with diabetes. N Engl J Med 2012;366:1567-76.

27. Peterli R, Steinert RE, Woelnerhanssen B, Peters T, Christoffel-Courtin $\mathrm{C}$, Gass $\mathrm{M}$, et al. Metabolic and hormonal changes after laparoscopic Roux-en-Y gastric bypass and sleeve gastrectomy: a randomized, prospective trial. Obes Surg 2012;22:740-8.

28. Lee WJ, Chong K, Ser KH, Lee YC, Chen SC, Chen JC, et al. Gastric bypass vs sleeve gastrectomy for type 2 diabetes mellitus: a randomized controlled trial. Arch Surg 2011;146:143-8. 